ROCZNIKI FILOZOFICZNE

Volume LXIX, issue 3-2021

DOI: https://doi.org/10.18290/rf21693-3

MIŁOSZ HOŁDA

DOMINIQUE LAMBERT

\title{
THE PROBLEM OF DIVINE HIDDENNESS IN THE CONTEXT OF SCIENCE
}

The problem of divine hiddenness is being discussed today primarily in the context of the "argument from hiddenness" proposed by J. L. Schellenberg. However, this is not the only problem area where this issue comes into play. There are two more areas where divine hiddenness becomes a challenge to contemporary thinkers. The first is the discussion around the "covering of God's face" (hester panim) that has been going on in philosophy and theology after Auschwitz. The second, which will become our focus in this paper, is being developed in scientific context. The problem occurring in all these areas can be put together in the form of the question: "Why is God not more obvious?"

Thinkers reflecting on divine hiddenness in the third of the areas indicated above struggle not only with the difficulty of finding traces of God's action in the world, but above all with the question of how to explain the fact that science can develop without taking into account the existence of God. According to Paul Draper, the problem of hiddenness in the context of science is related to the fact that science has provided natural explanations of phenomena for which explanations formerly appealed to God. This in turn, according to many, gives support to naturalism and shows the superiority of naturalism over supranaturalism (including theism). Draper writes: "The problem ... here is the question

MıŁosz HoŁda, PhD, Hab., Faculty of Philosophy, Pontifical University of John Paul II in Krakow; correspondence address: ul. Kanonicza 9/203, 31-002 Kraków, Poland; e-mail: milosz.holda@upjp2.edu.pl; ORCID: https://orcid.org/0000-0003-0649-2168.

Dominique Lambert, Prof. Dr Dr, Centre Universitaire Notre-Dame de la Paix, University of Namur; address for correspondence: 61 rue de Bruxelles, B-5000, Namur, Belgium; e-mail: dominique.lambert@unamur.be; ORCID: https://orcid.org/0000-0002-6415-3175. 
of why..., if God or other supernatural entities exist, science can completely ignore them and explain away so much."

In our paper we intend, following the argument formulated by Schellenberg, to propose a possible "argument from hiddenness in the context of science." We will then present the ways in which this argument can be countered. We will also propose a refutation of this argument in the form of a thesis of "explanatory absconditheism," the best expression of which is the thesis of the "articulation" of scientific and theological ways of explaining the world. Finally, we will show that the thesis of "explanatory absconditheism" can be extended to the entire discussion of God's hiddenness, providing one possible response to the "argument from hiddenness."

\section{THE ARGUMENT FROM HIDDENNESS IN THE CONTEXT OF SCIENCE}

Let us begin by recalling one version of the "argument from hiddenness" proposed by Schellenberg: ${ }^{2}$

(1) If a perfectly loving God exists, then there is such a God who is always open to a personal relationship with every finite personal being.

(2) If there is such a God who is always open to a personal relationship with every finite personal being, then no finite personal being is ever, in the absence of resistance on its part, in a state of disbelief regarding the claim that God exists.

(3) If a perfectly loving God exists, then no finite personal being is ever in a state of disbelief in the absence of resistance on its part regarding the claim that God exists [of 1 and 2].

(4) Some finite personal beings are or have been in a state of disbelief in the absence of resistance on their part regarding the claim that God exists.

(5) There is no perfectly loving God [of 3 and 4].

(6) If no perfectly loving God exists, then God simply does not exist.

(7) Therefore, God does not exist" [from 5 and 6].

Two conclusions can be drawn from Schellenberg's argument, if found convincing. One is a complete rejection of the thesis of the existence of God;

\footnotetext{
${ }^{1}$ Paul Draper, "God, Science, and Naturalism," in The Oxford Handbook of Philosophy of Religion, ed. William Wainwright (Oxford: OUP, 2005), 299.

2 J. L. Schellenberg, The Hiddenness Argument. Philosophy's New Challenge to Belief in God (Oxford: OUP, 2015), 103.
} 
the other is a rejection of the thesis of the existence of God as claimed by classical theism. What is interesting, Schellenberg presenting different versions of his argument initially leaned towards the first of these solutions - the atheistic one. ${ }^{3}$ Later, however, he advocated the position that he called "ultimism." The consequence of the "argument from hiddenness" is, according to "later" Schellenberg, the necessity to reject the thesis that God is a person. However, according to him, one can still carry out religious search, the more so because, contrary to the views of former atheists, science does not lead directly to atheism. ${ }^{4}$

Let us try to formulate an "argument from hiddenness in the context of science" based on the considerations carried out above. The key element of this argument will be Draper's thesis that it is possible to disregard God in the process of explaining the world (in other words, that science is perfectly capable of explaining the world even if it disregards God). The argument could take the following form:

(1) If God of classical theism exists, one cannot disregard Him when explaining the world.

(2) One can explain the world without taking God into account.

(3) God does not exist.

Phrased this way, the argument would argue for "atheism in the context of science."

However, one can propose, in the spirit of later versions of Schellenberg's argument, a more cautious version of the "argument from hiddenness in the context of science." The key premise of this more cautious version would concern the possibility of divine interventions in the world. The argument would thus take the following form:

(1) If God of classical theism exists, one cannot disregard His interventions when explaining the world.

(2) One can disregard God's interventions when explaining the world.

(3) God does not intervene in the world.

An argument formulated in this way would involve a modification of the classical theistic position, which assumes the possibility of divine interventions in the world.

\footnotetext{
${ }^{3}$ The first version was presented in J. L. Schellenberg, Divine Hiddenness and Human Reason (Ithaca, NY: Cornell University Press, 1993), 83.

${ }^{4}$ SCHELlenderg, The Hiddenness Argument, 232.
} 
The essential boundary between possible kinds of theism runs between concepts that presuppose divine interventions and those that do not. The dividing line, then, does not run between deism and concepts that presuppose, for example, that God sustains the world. From a metaphysical point of view, the difference between the thesis of the possibility of divine interventions in the world and the thesis of its impossibility is much greater than between the deistic thesis, devoid of the idea of sustaining the world by God, and the thesis that God sustains the world in existence.

If the argument presented above is found convincing, then a redefinition of the classical theistic conception of God intervening in the world appears necessary. An example of such redefinition is "naturalistic theism." It was born as an attempt to build a natural theology free from the error of the "God of the gaps." One version of "naturalistic theism" assumes the complete absence of God's intervention in the world. In doing so, however, it comes close to deism. Another version assumes interventions at the "micro" level. This strategy, however, seems to merely move the problem of the "God of the gaps" one level "down" from that of old-style natural theology. Arguments invoking the indeterminacy of the "micro" level are not conclusive. For they can be counterargued that the lack of determinacy is derived from our insufficient knowledge, not from the ontological character of reality itself, which can also be fully determined at the "micro" level. Moreover, a God who would have to hide His interventions behind the indeterminacy of the "micro" level seems a "strange" God. ${ }^{6}$ It is difficult to find an answer to the question of why God would have to refrain from intervening on the "macro" scale. To do so would unnecessarily diminish God's power, which, according to classical theism, can manifest itself in any domain He chooses. "Naturalistic theism" leads to a significant modification of the classical theistic thesis, and this solution is not acceptable to the supporters of classical theism. Let us therefore look at other possibilities.

It seems more promising to attack the assumption that, if the God of classical theism exists, one cannot disregard His interventions when explaining

\footnotetext{
${ }^{5}$ The best introduction and discussion of naturalistic theism can be found in Piotr BYLICA, Wspótczesny teizm naturalistyczny z punktu widzenia modelu poziomów analizy. Problem działania sfery nadnaturalnej w przyrodzie (Zielona Góra: Instytut Filozofii Uniwersytetu Zielonogórskiego, 2016).

${ }^{6}$ Michael Dodds suggests that if we think of God in the way that such concepts assume, God appears to be "strange" or to behave "strangely." These concepts assume the existence and action of a deceitful God who must do everything to ensure that His actions are not discovered. In place of God who formed the heavens with the earth, we have here a kind of divine statistician who must calculate carefully whether his action is subtle enough not to be detected by science. See Michael DodDS, Unlocking Divine Action (Washington: Catholic University of America Press, 2012), 158-59.
} 
the world. The objections to this premise can have several versions. We will try to formulate them by going back to the discussion around Schellenberg's argument. We will also add one premise that is not discussed in the context of Schellenberg's argument, but arises when the "argument from hiddenness in the context of science" is being discussed.

Many opponents of Schellenberg's argument share the belief that neither nonresistant nonbelief, nor any other of the problems of hiddenness, are sufficient reasons to reject the classical theistic thesis. They counter the "argument from hiddenness" in various ways: they clarify or modify slightly the thesis about the nature of God; they explain that either no nonbelief is such that it can be regarded as completely nonresistant or, on closer inspection, is not nonbelief at all; ${ }^{7}$ they point to reasons God might have for allowing nonresistant nonbelief; and they suggest that these reasons are not, or even cannot, be known to us. Let us begin with the last of these solutions.

It is characteristic of proponents of so-called "skeptical theism." It has been introduced into the discussion as a way of refuting a posteriori arguments for atheism, most notably the "evidential argument from evil." According to its proponents, "skeptical theism" offers a more sophisticated way of dealing with the argument from evil than typical theodicy does. ${ }^{8}$ The skeptical component of skeptical theism is used as a critique of so-called "noseeum inference." Skeptical theists suggest that this reasoning is used by proponents of the "evidential argument from evil." In the absence of apparent reasons why God should allow terrible evil in the world, the latter conclude that there are no such reasons. According to skeptical theists reasoning like this would be justified only if we could be sure that if such reasons existed, we would be able to perceive them. However, in their view, we should be skeptical precisely about our ability to perceive such reasons. ${ }^{9}$

Skepticism about our ability to have knowledge of the compelling reasons God might have for allowing evil is justified by appealing to the beliefs that we have no good reason to claim that the kinds of good we know are representative of all possible goods or that the kinds of evil we know are representative of all possible evils. What more we have no good reason to claim that the relations of attraction we know between possible goods and allowing possible evils are

\footnotetext{
${ }^{7}$ William WAINwright, "Jonathan Edwards and the Hiddenness of God," in Divine Hiddenness. New Essays, ed. Daniel Howard-Snyder and Paul Moser (Cambridge: CUP, 2002), 98-119; Matthew Benton, "God and Interpersonal Knolwledge," Res Philosophica 95 (2018): 421-47.

8 Justin McBraYer, "Skeptical Theism," Philosophy Compass 5 (2010): 612.

9 Michael Murray and David E. TAYLOR, "Hiddeness," in The Routledge Companion to Philosophy of Religion, ed. Chad Meister and Paul Copan (London: Routledge, 2007), 308-17.
} 
representative of the relations of attraction that occur between possible goods and allowing possible evils and that the total moral value or worthlessness that we discover in certain complex states of affairs properly reflects the moral value or worthlessness that those states of affairs actually possess. ${ }^{10}$

Countering the argument by appealing to the reasons given above, even if successful, still does not solve the problem of hiddenness. To deal with this problem, therefore, skeptical theists either emphasize the positive significance of mystery or seek positive reasons why we should expect the world to be just as it is if God exists (that is, that God is hidden). The kind of skeptical theism that involves the search for such reasons can be termed "positive skeptical theism" as opposed to "negative skeptical theism," which is focused solely on refuting a posteriori arguments against God's existence. In the case of "positive skeptical theism," the skeptical component arises from one's positive knowledge of God's reasons for creating a world where seemingly gratuitous evil exists (and where, we might add, God is hidden), whereas in the case of "negative skeptical theism," it is supported only by a belief in our inability to know God's reasons in for allowing seemingly gratuitous evil (and divine hiddenness). "Positive skeptical theists" do not claim to fully understand or see God's reasons for allowing evil or hiding. They do, however, argue that certain "second-order" justifications or implicit reasons that God may have for creating the world with seemingly futile evil and hiddenness are satisfactory. ${ }^{11}$

An example of such a justification is the belief that the appearance of seemingly gratuitous evil is the most effective way to create the "epistemic distance" that is necessary for humans to freely turn toward God and enter into a relationship with Him. The term "epistemic distance" was introduced into the discussion by John Hick. ${ }^{12}$ For him, "epistemic distance" is possible even though there is no "metaphysical" distance between God and the world. Even if God did sustain the world in existence, it would be possible and necessary for there to be an "epistemic distance" without which freedom and responsibility are not possible. Commenting on this view, it can be argued that "epistemic distance" is a condition for any behavior, choice, or way of thinking that can be described as fully human.

\footnotetext{
${ }^{10}$ Michael Bergmann, "Skeptical Theism and the Problem of Evil," in The Oxford Handbook of Philosophical Theology, ed. Thomas Flint and Michael Rea (Oxford: OUP, 2009), 376; Bergmann, "Commonsense Skeptical Theism," in Reason, Metaphysics, and Mind. New Essays on the Philosophy of Alvin Plantinga, ed. Kelly James Clark and Michael Rea (Oxford: OUP, 2012), 12.

${ }^{11}$ John DePOE, "On the Epistemological Framework for Skeptical Theism," in Skeptical Theism. New Essays, ed. Trent Dougherty and Justin McBrayer (Oxford: OUP, 2014), 33-34, 36, 38.

12 John Hick, Evil and the God of Love (New York: Palgrave Macmillan, 2010), 282-83.
} 
The second strategy of the opponents of Schellenberg's argument is to point to the possible goods that can arise as a result of God allowing unbelief without resistance to exist. It is pointed out that the hiddenness of God is not only not disadvantageous for human beings, but on the contrary, it is good for them because without it certain values essential for the full development of human beings could not be realized. God, according to the proponents of such a theodicy, hides Himself, for example, in order to check whether man does not respond to Him for the wrong reasons (for example, fear of hell), and therefore whether he seeks Him in purity of heart or to prevent people from treating God as merely a source of their own pleasure. ${ }^{13}$ All of proposed values reveal compelling possible reasons why God hides Himself. If these reasons can be considered rational, the "argument from hiddenness" loses its force.

Of the defences of classical theism that have emerged in the context of the problem of divine hiddenness, the one that has been formulated in the course of discussions conducted under the heading of "axiology of theism" seems particularly interesting. This discussion focuses on claims about the value of God's existence or non-existence (or, in other words, the difference His existence would make to the value of the possible world in general), not on claims about the value of belief in God or the benefits of having or not having faith. ${ }^{14}$

One of the most important position defended among others (pro-theism, neutralism, agnosticism and quietism) is so called anti-theism. Supporters of this position do not claim that God is bad but that-despite His supreme goodness - it would be bad (or at least worse) if He existed. His only "fault" is or could be the incompatibility of His existence with certain values. The values involved here are: privacy, independence, autonomy, certain kinds of dignity. The problem associated with these values is the possibility of realizing them assuming the existence of God. Anti-theists claim that such goods can only (or in an important sense only) be realized on the basis of atheism, and that is why we should not want God to exist.

According to Kirk Lougheed, ${ }^{15}$ these values can also be realized on the basis of theism under the assumption that God is sufficiently hidden. In other words: the experience of the aforementioned goods is possible if God exists but remains

13 Travis DumsDAY, "Divine Hiddenness as Deserved," Faith and Philosophy 31, no. 3 (2014): 286; Richard CORRIGAN, Divine Hiddenness. The Judeo-Christian God's Self Revelation (Gloucester: Philosophical Frontiers Press, 2008), 74.

${ }^{14}$ Guy Kahane, "Should We Want God to Exist?" Philosophy and Phenomenological Research 87 (2011): 674-75.

${ }^{15}$ Kirk LougheED, "The Axiological Solution to Divine Hiddenness," Ratio 31, no. 3 (2018): $332-33$. 
hidden. The proposed solution to the problem of hiddenness is that God can hide in order to increase or maximize the axiological value of the world. "The Theistic World in which God is phenomenologically hidden" (God exists and is hidden from humans) and "The Atheistic World" (God does not exist) are identical or very similar in many aspects. Ontologically, however, they are radically different. Lougheed argues that all the goods associated with atheism can be experienced in a "Theistic World in which God is phenomenologically hidden." If this is true, then one cannot point to these goods as justifying the axiological asymmetry between theism and atheism even for individuals. One can see no reason, Lougheed argues, why anyone would not prefer a "Theistic World in which God is phenomenologically hidden," especially when one considers all the additional goods that might then arise if theism is true.

In a "Theistic World in which God is Phenomenologically Hidden," one can experience privacy with respect to God, independence, and autonomy. In such a world, cooperation between people is possible, because if we do not know whether God exists, we have no choice but to cooperate with each other to solve various problems. God, therefore, remains hidden to make sure that people can experience an array of goods that they would not otherwise experience. The result of His hiddenness is a world more valuable than one in which God's existence is obvious. The goods that result from God's hiddenness in a "Theistic World in which God is phenomenologically hidden" merge with the goods that result from God's existence. In a world in which God exists, gratuitous evil is impossible (because God is able to use every evil for a good purpose and thus make it "good"), cosmic justice occurs, and life after death is possible (and even guaranteed). All this, according to Lougheed, makes it axiologically preferable to consider a "Theistic World in which God is phenomenologically hidden." And if so, we find an explanation of the fact of God's hiddenness. We might add that we also find a reason for wanting God to be rather than wanting Him not to be. ${ }^{16}$

\section{POSSIBLE REBUTTALS TO THE “ARGUMENT FROM HIDDENNESS IN THE CONTEXT OF SCIENCE"}

The above solutions to the problem of hiddenness that appear in the context of Schellenberg's argument can be adapted to the discussion around the "argument from hiddenness in the context of science." An adequate version of skeptical

\footnotetext{
${ }^{16}$ Ibid., 336-39.
} 
theism would include the thesis that because God is a non-physical entity, we cannot expect to be able to ascertain His interventions in the world. Moreover, God's omnipotence allows Him to act in ways that may elude our cognitive abilities. Such an explanation could be taken as a "positive" because, assuming classical theism, the impossibility of ascertaining God's interventions is precisely what would be expected if theism were true. It may also be noted that the impossibility of ascertaining God's interventions in the world is necessary so that an "epistemic distance" can be produced. Without such a distance, it would be difficult to think of any natural explanations and the possibility of preserving the "methodological naturalism" that is crucial to science.

It is also not difficult to identify the goods that come into play with respect to the problem of divine hiddenness considered in the context of science. The most important of them are our cognitive autonomy, the possibility of satisfying human ambitions in learning about the world, developing cognitive passion, which is an essential part of the approach to science, as well as the possibility of cooperation consisting in creating a community of researchers. These goods would be impossible to realize if it were necessary to take into account God's intervention in the processes of scientific explanation. The broadest way to put it is that if God were manifest, science could not be science as we know it - a natural reflection on the world. It would be at best a theology of nature.

The goods mentioned above, however, are not yet all the possible goods that can be thought of. There are goods that can be described as goods that accompany the scientific process. The goods referred to are not merely psychological in nature (although this element is not without significance either), but are related to the epistemic justification of the purpose of science. According to Georges Lemaître, the appeal to a "hidden God" is psychologically beneficial, since it creates an optimistic "background" for scientific investigation. He wrote: "The believer has perhaps the advantage of knowing that the mystery has a solution, that the ultimately hidden writing is the work of an intelligent being, and that therefore the problem posed by nature can be solved, and that the difficulty is undoubtedly adapted to the present or future capacity of mankind. Perhaps this would not give him new means of investigation, but it would help to sustain him in a healthy optimism, without which the effort made cannot long be sustained." 17

17 Dominique LAMBerT, L'itinéraire spirituel de Georges Lemaître (Bruxelles: Lessisus, 2007), 128 
Similarly, Michał Heller ${ }^{18}$ reminds that the assumption that science is not only the study of the world but can also be the discovery of God's design placed in this world plays an important role by providing reasons for seeing the value of scientific cognition of the world.

It is also pointed out that scientific cognition is not just a reflection on the world and its conditions, but is increasingly linked to a sensitivity to the drama of existence. If science is to provide ways of dealing with life experiences, the assumption that there exists something "more" is the best way for this connection to take place. The belief in the existence of a "hidden God" also makes it possible to connect the scientific study of nature with other areas of life. Józef Życiński ${ }^{19}$ wrote:

Some processes, however, reveal His presence in a manner more readily accessible to our cognition. To these, besides the order of the laws of nature, belongs the domain of our aesthetic or moral experience. Other manifestations of this beauty are experienced in contact with human nobility, altruism, holiness. The moral harmony discovered in this experience is the anthropological equivalent of the order of nature, while its structure remains in direct relation to the ethical ideals defined by God. The realm of experience of these ideals is intrinsically the realm of the encounter with God, who comes incognito.

The benefit of appealing to the hidden God is thus also the possibility of integrating science into the totality of life. The above-mentioned benefits of one kind and another can be combined only if God can be disregarded in the processes of scientific explanation of the world.

A final way to undermine the premises of the "argument from hiddenness in the context of science" might be to appeal to the notion of "explanation." Referring to this notion, one can attack the second premise of the argument, according to which it is possible to disregard God's interventions when explaining the world. We mentioned above that Schellenberg's argument is sometimes countered by challenging the claim that we may be dealing with non-resistant nonbelief at all. In the context of the argument we are interested in, it can be argued that scientific explanation is not a complete explanation. One way to put this is that scientific explanation is a "penultimate explanation" and as such may not include God. An "ultimate explanation," on the other hand, would have to take into account God's existence and, what is more, God's activity in the world. By claiming this, one does not presuppose

\footnotetext{
${ }^{18}$ Heller, Michał, Granice nauki (Kraków: Copernicus Center Press, 2014), 14.

${ }^{19}$ Józef ŻYCIŃSKI, Naturalizm i transcendencja (Kraków: Copernicus Center Press, 2014), 175.
} 
the existence of "gaps" within science that would have to be filled in by God. However, the existence of "gaps" on the borders of science is admitted. These gaps may be ontological, epistemological, and axiological. A full explanation would therefore have to take into account the necessity of filling them.

It may be added that an explanation built on the thesis of "ontological naturalism," which is based on "methodological naturalism" - the necessary methodological directive to create science free from the pernicious influence of metaphysical admixtures - may also be considered "penultimate." The transition from "methodological naturalism" to "ontological naturalism," although it seems to be to some extent justified not only philosophically but also psychologically, is neither necessary nor beneficial for science.

Each of the strategies outlined above for rebutting the premises of the "argument from hiddenness in the context of science" contains some essential element that could be used to formulate a cumulative counterargument against the "argument from hiddenness." However, we want to offer another solution. In the following, we will present a position that could be described as "explanatory absconditheism." It will be an absconditeism that is conservative in character and thus seeks to defend the thesis of the existence of God of classical theism-a God, especially importantly, capable of intervening in the world. We will show that this position gathers in itself the positive features of all the above-mentioned strategies, and should therefore be regarded as a particularly valuable strategy for countering the "argument from hiddenness in the context of science." We will also show how this position can contribute to dealing with Schellenberg's argument itself.

\section{EXPLANATORY ABSCONDITHEISM}

Absconditheisms are theistic concepts that are formulated in response to problems of hiddenness discussed in various problem areas. Each absconditheism contains two theses: 1) God exists (theistic thesis); 2) God is hidden (thesis about hiddenness). Those of the absconditheisms that do not lead to a modification of the classical "theistic thesis," but focus on developing a "thesis about hiddenness," can be called "conservative absconditheisms." Those which, under the influence of the "thesis about hiddenness," lead to a modification of the "theistic thesis," can be called "reformist absconditheisms." 20

${ }^{20}$ On the concept of absconditheism see Miłosz HoŁDA, Źródło i noc. Wprowadzenie do wspótczesnego absconditeizmu (Kraków: WAM, 2020). 
In this text we argue for a conservative absconditheist position formulated in the context of scientific explanation. This position holds that God not only exists and possesses the features attributed to Him in classical theism, but can also intervene in the world.

In the context of modern science, a strategy that can be called abscondithesitic, because it involves appealing to the idea of a "hidden God," was pioneered by Georges Lemaître cited above. He used the concept of "hidden God" not only for theological reasons, but also to defend the philosophical neutrality of the "Primeval Atom" hypothesis. Lemaitre maintained that God-according to the saying of the prophet Isaiah (Isa. 45:15) — is a "hidden God" and does not reveal Himself only in the gaps of human knowledge. $\mathrm{He}$ suggested that God is hidden but not "absent." He reminded that the believing scientist does not mix God into his theories, although God gives all His actions "the depth of eternity." 21 Lemaitre appealed to the thesis of a hidden God because he wanted to avoid too easy concordism.

There are several ways of combining scientific theses with theses from theology. ${ }^{22}$ The first one is concordism. To put it simply, according to this strategy the theses of science and theology would eventually "overlap" (the theological theses would "absorb" the scientific theses or, conversely, the scientific theses would "absorb" the theological ones) or at least it would be possible to show that it is possible to derive the scientific theses from the theological theses or the theological theses from the scientific ones. This strategy can occur in ontological, epistemological and ethical versions (it can also be called axiological). In the context of the problem we are interested in, we should say that according to concordism God, if $\mathrm{He}$ intervened in the world, would have to be visible in science - in other words, scientific explanations could not disregard Him. In the opposite version - when we take into consideration the possibility of "absorbing" the theological theses by science-concordism would lead to the thesis that science is able to give the proof for the non-existence of God, which would be based on scientific explanations. Any thesis about God's action in the world would then have to be treated at most as a metaphor describing natural (and describable to science) events happening in the world.

The opposite position to concordism is discordism. It, too, can appear in the three versions mentioned above. In the context of the issue that interests us,

${ }^{21}$ LAMBERT, L'itinéraire spirituel de Georges Lemaître (Bruxelles: Lessisus, 2007), 127.

${ }^{22}$ On possible models for the relationship between science and theology see Dominique LAMBERT, Sciences et Théologie. Les figures d'un dialogue (Bruxelles: Lessius, 1999), 73-129. 
it should be treated as a thesis that scientific explanations and theological explanations are competing ways of explaining phenomena occurring in the world. The consequence of such a position is that either two contradictory "truths" must be maintained - one of a scientific nature and the other of a theological nature - or a choice must be made between these kinds of explanations.

We seem to be in a situation of a necessary choice between concordism and discordism. However, another solution can be proposed. It is the strategy of articulation. ${ }^{23}$ As with the above strategies, three versions are possible. The necessity to take into account the articulation strategy seems to be particularly important in the context of explaining the existence of the universe. It is not possible to explain it only by appealing to science, because it has no access to the "source of existence." If we want to answer the question why the world exists, we should invoke the idea of creation. Creation can be interpreted as a "meta-physical" relation by which God "establishes the universe in its being." This act on God's part simultaneously brings into being and establishes the fundamental difference that makes it impossible to confuse God with the world. The union of God with the universe is thus truly metaphysical.

The metaphysical question does not overlap with scientific questions from the outside. It joins them by giving scientists access to answers they could not find by limiting themselves to their methods. An adequate explanation of the world involves not only the "foundation" of being, but also concerns the autonomy of the world. There is an "ontological mediation" between God and the world. Only when this mediation is relational does true "union" occur. It constitutes a unifying relationship and at the same time a sustaining difference. An explanation of how unification occurs without identification is only possible if one considers the category of purpose. A physical system is coherent if it has regularities, if it has laws that organize its components into a whole. Final cause is not a "mere" cause, but the cause of causes (causa causarum according to scholastic nomenclature). It is it that explains the unfolding and operation of causes of other kinds. Final causation is not on the same level as the other kinds of causes. This kind of causality does not destroy the order of causes that a physicist or biologist can reveal, but explains their unfolding. It can be said that God's relation to the world is to "establish" the world in being and to "pre-settle" a plurality of purposes. It is not, therefore, merely sustaining in existence. There is communication between God and the world. God

\footnotetext{
${ }^{23}$ Jean Ladrière was the first to propose this way of relating science and theology — see Jean LADRIÈRE, L'articulation du sens. Discours scientifique et parole de la foi (Paris: Aubier Montaigne, Cerf, Delachaux \& Niestlé, De Brouwer, 1970); and LADRIÈRE's L'articulation du sense, vols. 1, 2, and 3 (Paris: Cerf, 1984-2004).
} 
remains present in the world, but not as a secondary cause. The modus of His presence is the cause of causes. Although located on a different level than physical causes, God can actually and currently be present in the world to varying degrees. When we think about God's activity in the world we can say, that God hides himself because His action is discreet. He does not break up the autonomy of immanence. Through the cause of causes, He is that which induces autonomy of natural causes.

This model preserves the necessary autonomy of the levels of reality while not limiting God's "freedom" as to the ways in which $\mathrm{He}$ could be present in the world. It describes the way God interacts with the universe that respects His transcendence and His "right to visit" our world. It also implies some subtle form of intervention. It reinterprets naturalistic theism by placing it in causal categories taken over from classical metaphysics, with an emphasis on the importance of one of them, the final cause. A more important addition, however, seems to be the postulate of the possibility of intervention in a different, stronger sense than is assumed by weak naturalistic theism (not only at the "micro" level), and the related avoidance of the need to modify the classical theistic thesis.

Let us look at the advantages of this model by contrasting it with the possible solutions discussed above. This model contains the positive features of skeptical theism. Since God transcends the categories used by science, one cannot expect to be able to see Him in scientific research. The inability to find traces of His intervention in the realm of scientific explanation is precisely what is to be expected if the classical theistic thesis is true. The inability to ascertain His action is evidence of the occurrence of the necessary epistemic distance that allows for an explanatorily appropriate reference to God.

Our proposed model provides the possibility of establishing all possible goods that are associated with the practice of science: cognitive autonomy; the possibility of satisfying human ambitions in learning about the world; the possibility of developing cognitive passion, which is an essential part of the approach to science; the possibility of cooperation consisting in creating a community of researchers. It also allows us to take into account all the possible good that comes from the possibility of taking God into consideration at the level of metaphysical and theological explanations: the optimistic psychological "background" of the study of the world; the justification of the assumption that science is not only the study of the world, but it can also be the discovery of God's plan placed in this world, which provides the reasons for seeing the value of scientific cognition of the world; the possibility of combining the 
scientific study with the reflection on the world and its conditions, which allows us to take into account the drama of existence.

This model also helps to show the relationship between levels of explanation. Scientific explanations, in which God can be disregarded, would appear as "penultimate" while theological explanations would appear as "ultimate." This kind of combination of explanations, in which there is a level at which God's action can be disregarded and a level at which it is possible, even necessary, to take God into account, would appear to be the best from a cognitive point of view. The existence of such a model would thus constitute an epistemological argument that can be used in the discussion of issues that belong to the "axiology of theism." A science-theology relationship that has the character of "articulation" would appear to be better than a "concordism" relationship (in which God would be manifest in science), and "discordism" (according to which no explanation referring to God could come into play).

\section{EXPLANATORY ABSCONDITHEISM AND SCHELLENBERG'S ARGUMENT}

The solution presented above also seems to be of interest in the context of the discussion surrounding Schellenberg's argument. The problem there is to treat the theological explanation, which presupposes the existence of God, and the scientific explanation on the same level. Schellenberg suggests that rational unbelief would be evidence for the non-existence of God (at least the God of classical theism). Following his line of thought, one would have to conclude that nonresistant nonbelief would be impossible only if, at the level of experience of the world, it were possible to experience God in purely natural terms. To put it more simply, this scheme would assume that among events that can be described and explained naturally, something must occur that can be explained naturally as an experience of God (or a sign or proof of His existence). The problem is that this approach settles the exploratory problem immediately in favor of concordism. For theological explanation must be reducible to natural explanation.

In the light of "explanatory absconditheism" it is possible to conceive the relation between "natural" explanations, and the explanation that is God, as complementary explanations. The world can appear as completely natural. An explanation of the world is possible in pure natural terms. This does not mean, however, that what we take to be the ultimate horizon of the world is not merely a veil that obscures the possibility of seeing God working in the world 
in as many ways as he wishes - both through natural phenomena and in ways whose supernaturalness cannot be grasped by methods designed for the study of natural phenomena. Considering the solution presented above provides an opportunity to consider the possibility of viewing the world from a broader perspective that in no way violates the scientific perspective and not only provides additional goods that are not possible without considering theistic explanations, but above all allows for the rational conviction that the world we come to know through science is not yet all that exists.

\section{BIBLIOGRAPHY}

Alston, William. "The Inductive Argument from Evil and the Human Cognitive Cognition." Philosophical Perspectives 5 (1991): 29-67.

Benton, Matthew. “God and Interpersonal Knolwledge.” Res Philosophica 95 (2018): 421-47.

Bergmann, Michael. "Commonsense Skeptical Theism.” In Reason, Metaphysics, and Mind. New Essays on the Philosophy of Alvin Plantinga, edited by Kelly James Clark and Michael Rea, 9-37. Oxford: Oxford University Press, 2012.

Bergmann, Michael. "Skeptical Theism and the Prolbem of Evil." In The Oxford Handbook of Philosophical Theology, edited by Thomas Flint and Michael Rea, 374-99. Oxford: Oxford University Press, 2009.

BYLICA, Piotr. Wspótczesny teizm naturalistyczny z punktu widzenia modelu poziomów analizy. Problem działania sfery nadnaturalnej w przyrodzie. Zielona Góra: Instytut Filozofii Uniwersytetu Zielonogórskiego, 2016.

Corrigan, Richard. Divine Hiddenness. The Judeo-Christian God's Self Revelation. Gloucester: Philosophical Frontiers Press, 2008.

Depoe, John. "On the Epistemological Framework for Skeptical Theism.” In Skeptical Theism. New Essays, edited by Trent Dougherty and Justin McBrayer, 32-44. Oxford: Oxford University Press, 2014.

DodDS, Michael. Unlocking Divine Action. Washington: Catholic University of America Press, 2012.

DrAPER, Paul. "God, Science, and Naturalism." In The Oxford Handbook of Philosophy of Religion, edited by William Wainwright, 272-303. Oxford: Oxford University Press, 2005.

Dumsday, Travis. "Divine Hiddenness as Deserved." Faith and Philosophy 31, no. 3 (2014): 286-302.

DuMSDAY, Travis. "Anti-Theism and the Problem of Divine Hiddenness." Sophia 55 (2016): 179-95.

Green, Adam, and Eleonore Stump. Hidden Divinity and Religious Belief. Cambridge: Cambridge University Press, 2015.

HeLler, Michał. Granice nauki. Kraków: Copernicus Center Press, 2014.

Hick, John. Evil and the God of Love. New York: Palgrave Macmillan, 2010.

HoŁDA, Miłosz. Źródło i noc. Wprowadzenie do współczesnego absconditeizmu. Kraków: WAM, 2020.

Kahane, Guy. "Should We Want God to Exist?" Philosophy and Phenomenological Research 87 (2011): 674-96. 
LADRIÈRE, Jean. L'articulation du sens. Discours scientifique et parole de la foi. Paris: Aubier Montaigne, Cerf, Delachaux \& Niestlé, De Brouwer, 1970.

LADRIERE, Jean. L'articulation du sens. Vol. 1, Discours scientifique et parole de foi. Paris: Cerf, 1984.

LADRIERE, Jean. L'articulation du sens. Vol. 2, Les langages de la foi. Paris: Cerf, 1984.

LAdriere, Jean. L'articulation du sens. Vol. 3, Sens et vérité en théologie. Paris: Cerf, 2004.

LAMBERT, Dominique. L'itinéraire spirituel de Georges Lemaître. Bruxelles: Lessisus, 2007.

LAMBERT, Dominique. Sciences et Théologie. Les figures d'un dialogue. Bruxelles: Lessius, 1999.

LougheEd, Kirk. "The Axiological Solution to Divine Hiddenness." Ratio 31, no. 3 (2018): 331-41.

MCBrayer, Justin. "Skeptical Theism.” Philosophy Compass 5 (2010): 611-23.

Murray, Michael, and David E. TAYLOR. "Hiddenness." In The Routledge Companion to Philosophy of Religion, edited by Chad Meister and Paul Copan, 308-17. London: Routledge, 2007.

SChellenberg, John L. Divine Hiddenness and Human Reason. Ithaca, NY: Cornell University Press, 1993.

SChellenberg, John L. The Hiddenness Argument. Philosophy's New Challenge to Belief in God. Oxford: Oxford University Press, 2015.

WAinwright, William. "Jonathan Edwards and the Hiddenness of God." In Divine Hiddenness. New Essays, edited by Daniel Howard-Snyder and Paul Moser, 98-119. Cambridge: Cambridge University Press, 2002.

ŻYCIŃSKI, Józef. Naturalizm i transcendencja. Kraków: Copernicus Center Press, 2014.

\section{THE PROBLEM OF DIVINE HIDDENNESS IN THE CONTEXT OF SCIENCE}

\section{S u m m a ry}

The aim of the paper is to try to find a solution to the problem of divine hiddenness, which in the context of science takes the form of the question of why, if God exists, science can completely ignore Him and yet explain away so much. We formulate the "argument from hiddenness in the context of science" modelled on the "argument from hiddenness" proposed by J. L. Schellenberg and show possible ways to refute this argument. We also propose a refutation in the form of "explanatory absconditheism," the best expression of which is the thesis of "articulation" of scientific and theological ways of explaining the world. We also argue that the thesis of "explanatory absconditheism" can be extended to the entire discussion of divine hiddenness, providing possible response to the "argument from hiddenness."

Keywords: divine hiddenness; science; absconditheism; discordism; concordism; articulation. 


\section{PROBLEM BOŻEJ UKRYTOŚCI W KONTEKŚCIE NAUKI}

\section{Streszczenie}

Celem artykułu jest próba znalezienia rozwiązania problemu Bożej ukrytości, który w kontekście nauki przybiera postać pytania o to, dlaczego, jeśli Bóg istnieje, nauka może Go całkowicie ignorować, a mimo to tak wiele wyjaśniać. Formułujemy „argument z ukrytości w kontekście nauki” na wzór „,argumentu z ukrytości” zaproponowanego przez J. L. Schellenberga i pokazujemy możliwe sposoby obalenia tego argumentu. Proponujemy również refutację tego argumentu w postaci ,absconditeizmu eksplanacyjnego," którego najlepszym wyrazem jest teza o „zespojeniu” naukowych i teologicznych sposobów wyjaśniania świata. Argumentujemy również, iż teza „absconditeizmu eksplanacyjnego” może zostać rozszerzona na całą dyskusję o ukryciu Boga, dostarczając możliwej odpowiedzi na ,argument z ukrytości”.

Słowa kluczowe: Boża ukrytość; nauka; absconditeizm; dyskordyzm; konkordyzm; zespojenie. 